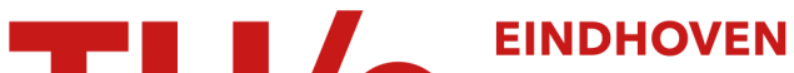 \\ UNIVERSITY OF \\ TECHNOLOGY
}

\section{Reaction of polyvinyl alcohol with aluminum isopropoxide}

Citation for published version (APA):

Hippe, R., \& German, A. L. (1978). Reaction of polyvinyl alcohol with aluminum isopropoxide. European Polymer Journal, 14(10), 845-847. https://doi.org/10.1016/0014-3057(78)90184-2

DOI:

10.1016/0014-3057(78)90184-2

Document status and date:

Published: 01/01/1978

\section{Document Version:}

Publisher's PDF, also known as Version of Record (includes final page, issue and volume numbers)

\section{Please check the document version of this publication:}

- A submitted manuscript is the version of the article upon submission and before peer-review. There can be important differences between the submitted version and the official published version of record. People interested in the research are advised to contact the author for the final version of the publication, or visit the $\mathrm{DOI}$ to the publisher's website.

- The final author version and the galley proof are versions of the publication after peer review.

- The final published version features the final layout of the paper including the volume, issue and page numbers.

Link to publication

\section{General rights}

Copyright and moral rights for the publications made accessible in the public portal are retained by the authors and/or other copyright owners and it is a condition of accessing publications that users recognise and abide by the legal requirements associated with these rights.

- Users may download and print one copy of any publication from the public portal for the purpose of private study or research.

- You may not further distribute the material or use it for any profit-making activity or commercial gain

- You may freely distribute the URL identifying the publication in the public portal.

If the publication is distributed under the terms of Article 25fa of the Dutch Copyright Act, indicated by the "Taverne" license above, please follow below link for the End User Agreement:

www.tue.nl/taverne

Take down policy

If you believe that this document breaches copyright please contact us at:

openaccess@tue.nl

providing details and we will investigate your claim. 


\title{
REACTION OF POLYVINYL ALCOHOL WITH ALUMINIUM ISOPROPOXIDE
}

\author{
Rita Hippe* and ANTON L. German \\ Eindhoven University of Technology, Laboratory of Polymer Chemistry, P.O. Box 513. \\ Eindhoven. The Netherlands
}

(Received 26 January 1978)

\begin{abstract}
The uncatalyzed and oxalic acid catalyzed modification of polyvinyl alcohol (PVA) with aluminium isopropoxide have been studied for reaction in a suspension of powdered PVA in boiling benzene. Isopropyl alcohol (IPA) formed during the reaction was removed by continuous distillation of an IPA-benzene mixture. The reaction was initially quite fast but slowed up rapidly and practically stopped when only $4-12 \%$ of the $\mathrm{OH}$-groups had reacted. Thermogravimetric analysis (TGA) showed that products with 6.8 mole $\mathrm{Al} / 100$ mole VA exhibit a significant rise in decomposition temperature from 250 to $285^{\circ}$. The characteristics are attributed to the occurrence of vicinal OH-groups in PVA.
\end{abstract}

\section{INTRODUCTION}

We have reported the reaction of aluminium alkoxides with free $\mathrm{OH}$-groups present in polyvinyl butyral $[1,2]$. The modified polymer showed interesting properties including improved thermostability [3]. It appeared that the stability increased substantially by converting only very few $\mathrm{OH}$-groups into alumoxy groups, suggesting that specific $\mathrm{OH}$-groups are involved. It seemed to be interesting to study the incorporation of aluminium into polyvinyl alcohol (PVA) by reaction with aluminium alkoxides and to examine the products. Many modifications of PVA involving reactions of $\mathrm{OH}$-groups have been studied, including esterification, sulphonation and phosphorylation [4] but reaction with aluminium alkoxides has not been reported.

\section{EXPERIMENTAL}

\section{Reagents and solvents}

The following (pro analysi) reagents and solvents were used : benzene, oxalic acid (Merck), aluminium isopropoxide m.p. 124 (Merck-Schuchardt), polyvinyl alcohol (Elvanol 71-30, Dupont, average degree of polymerization 1800 , technical grade, powdered, particle size 5-10 $\mu$ ).

Reaction of polyvinyl alcohol with aluminium isopropoxide

The reaction was carried out in suspension using a flask fitted with stirrer, thermometer and fractionating column $(40 \mathrm{~cm})$. PVA (1 mole of VA units) was introduced into the flask and a filtered solution of Al-isopropoxide (from 0.1 mole to 1 mole) in $600 \mathrm{ml}$ benzene, was added. Then the suspension was stirred and heated.

The isopropyl alcohol (IPA) formed during the reaction was removed directly from the flask by continuous distillation of an IPA (b.p. $82.3^{\circ}$ )-benzene (b.p. $80.1^{\circ}$ ) mixture at a constant rate of $0.5 \mathrm{~cm}^{3} / \mathrm{min}$. These components form an azeotrope (b.p. $71.5^{\circ} ; 39.4$ mole \% IPA). During the reaction, benzene was added to compensate for loss by distillation. The first distillate was collected at approx $74^{\circ}$, then

* Permanent address: Institute of Chemical Technology, J. Lukasiewicz Technical University, Rzeszów, Poiand. the temperature rose as the IPA content of the distillate decreased, and finally practically pure benzene distilled off.

During the entire course of the reaction, the composition of the distillate was determined by GLC (Figs 1 and 2). The GLC analysis of the distillate was carried out on a gaschromatograph with a flame ionization detector (Hewlett-Packard type 5750, with carrier gas helium, liquid phase squalane, column temperature $130^{\circ}$ ). Retention times and peak areas were recorded on an electronic integrator (Hewlett-Packard type 3382). The distillate composition was confirmed by i.r.-analysis (Hitachi Grating Infrared Spectrophotometer, type EPI-G04).

After $5 \mathrm{hr}$ (except for experiment 2, after $8 \mathrm{hr}$ ) the reaction was stopped and the product was filtered off, washed

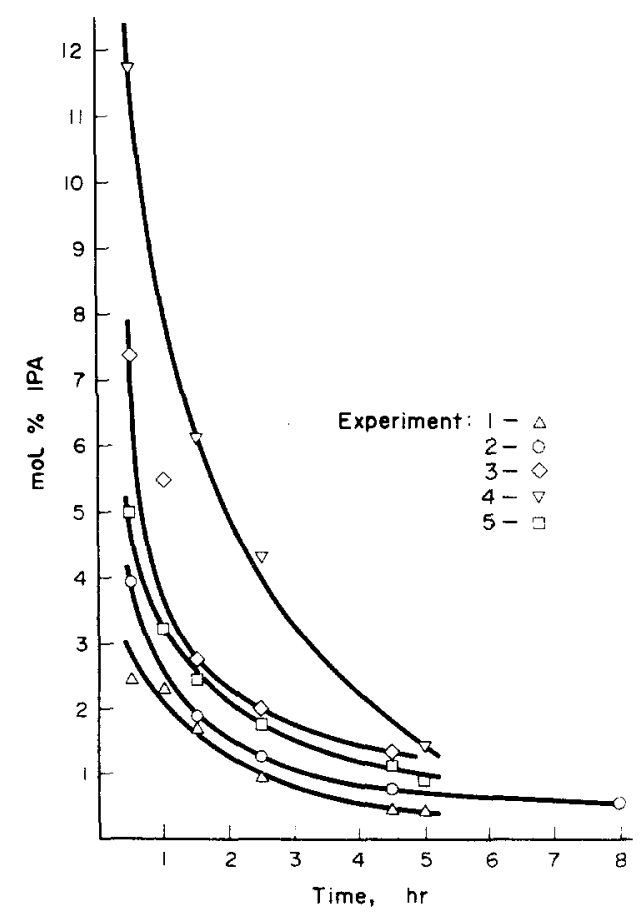

Fig. 1. IPA content of the instantaneous distillate, as a measure of the rate of conversion of OH-groups in PVA vs reaction time for experiment 1-5 (Table 1) 


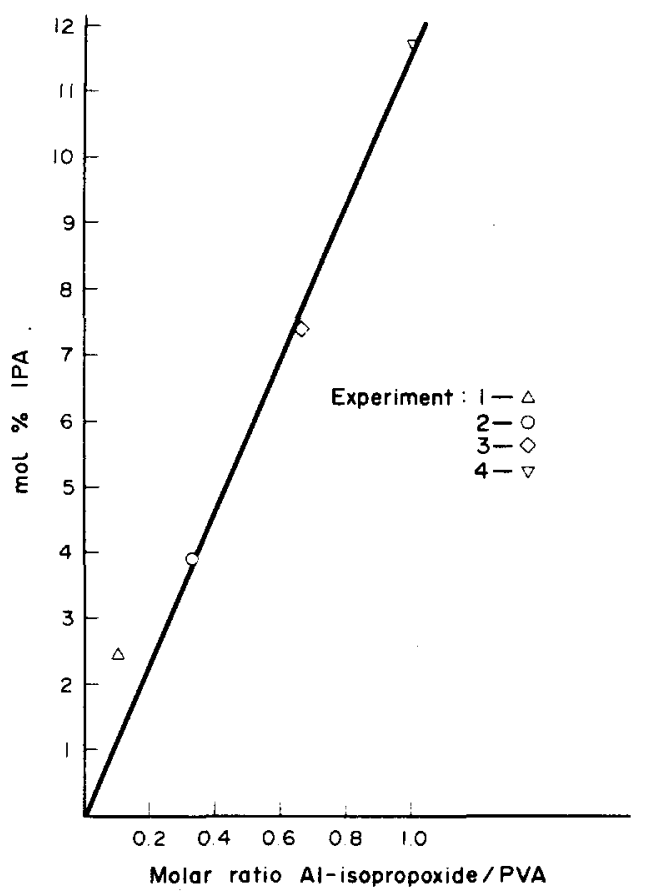

Fig. 2. IPA content of the distillate instantaneously collected after $30 \mathrm{~min}$ reaction time, as an approximate measure of the initial rate of conversion of OH-groups in PVA vs the initial molar ratio Al-isopropoxide/PVA for experiments 1-4 (Table 1).

with benzene and dried for $48 \mathrm{hr}$ at $60^{\circ}$ under vacuum. The aluminium content (a) of the polymer obtained was determined by calcination [5].

The results of the experiments and some blank determinations are given in Table 1. Determination of IPA in the total amount of distillate permits calculation of the degree of substitution (s) of the OH-groups in PVA (mono-, bi- and trifunctional reaction of $\mathrm{Al}$-isopropoxide). From the latter value (s) combined with the weight $\% \mathrm{Al}$ in the polymer $(a)$, the average functionality $(n)$ of Al-isopropoxide in reaction with OH-groups in PVA can be calculated from Eqn (1).

$$
n=\frac{s(2700-204 a)}{a(4400-60 s)} .
$$

The number of moles $\mathrm{Al} / 100$ mole VA units $(s / n)$ was calculated (Table 1).
Thermogracimetric analysis of the products

Dynamic TGA analysis was performed on a Mettler Vacuum Thermoanalyzer, heating rate $15 / \mathrm{min}$, in argon atmosphere (see Table 1).

\section{RESULTS AND DISCUSSION}

The reaction cannot easily be carried out in solution since suitable common solvents for PVA and Alisopropoxide are not available. In some solvents (e.g. acetylacetone, ethyl acetoacetate, toluene and DMF) only dark products were obtained. The reaction was also carried out by melting a mixture of PVA and Al-isopropoxide. Although reaction occurred, the i.r. spectra of the products showed double bonds indicating decomposition. The best results were obtained in suspension by carrying out the reaction of PVA with Al-isopropoxide in boiling benzene.

The presence of strongly acidic catalysts e.g. hydrochloric acid cause discolouration of the reaction mixture and the products, but oxalic acid did not induce any unfavourable effects.

The products (PVA modified with Al-isopropoxide) appeared to be slightly soluble only in hot dichloroacetic acid, whereas the unmodified PVA was readily soluble in hot water, hot DMF, acetylacetone and cold dichloroacetic acid.

From the data in Table 1 , it is evident that an increase of the Al-isopropoxide/PVA ratio does not significantly affect the aluminium content ( $a$ or $s / n$ ) of the products, at least for the uncatalyzed reactions and for the conditions studied. On the other hand, increase of the Al-isopropoxide/PVA ratio leads to an increased IPA production, i.e. increased degree of substitution (s) of OH-groups in PVA. As a consequence, the functionality (n) of Al-isopropoxide in reaction with $\mathrm{OH}$-groups increases from 1.0 to 2.8 (maximum value 3.0).

As in many other modification reactions of PVA [6], the catalyst plays an important part. For the acid-catalyzed reaction (experiment 5), the Al-content of the product $(a$ or $s / n)$ increases significantly whereas the functionality $(n)$ is the same as in the corresponding uncatalyzed reaction (cf. experiments 2 and 5).

Evidently, the catalyst increases the Al-content but does not affect the relative occurrence of primary, secondary and tertiary reactions of Al-isopropoxide

Table 1. Summary of experimental and computed data for some typical experiments

\begin{tabular}{|c|c|c|c|c|c|c|}
\hline $\begin{array}{c}\text { Exp. } \\
\text { number }\end{array}$ & $\begin{array}{c}\text { Initial molar } \\
\text { ratio of } \\
\text { Al-isopropoxide/ } \\
\text { PVA* }^{*}\end{array}$ & $\begin{array}{l}\text { Al-content } \\
\text { of products } \\
\text { (a) in wt \% }\end{array}$ & $\begin{array}{c}\text { Degree of sub- } \\
\text { stitution of } \\
\text { OH-groups in PVAt } \\
(s) \text { in } \%\end{array}$ & $\begin{array}{c}\text { Functionality } \\
\text { of Al- } \\
\text { isopropoxide } \\
\text { in reaction } \ddagger \\
(n)\end{array}$ & $\begin{array}{c}\text { Mole Al/ } \\
100 \text { mole } \\
\text { VA } \\
(s / n)\end{array}$ & $\begin{array}{l}\text { Primary } \\
\text { decomp. } \\
\text { temperature. } \\
\text { TGA } \\
\left({ }^{\circ} \mathrm{C}\right)\end{array}$ \\
\hline 1 & 0.10 & 2.33 & 4.4 & 1.0 & 4.4 & $\rightarrow$ \\
\hline 2 & 0.33 & 2.76 & 5.9 & 1.1 & 5.4 & 250 \\
\hline 3 & 0.66 & 2.77 & 8.2 & 1.6 & 5.1 & 250 \\
\hline 4 & 1.00 & 2.46 & 11.6 & 2.8 & 4.1 & 250 \\
\hline 5 & 0.33 & 3.41 & 7.5 & 1.1 & 6.8 & 285 \\
\hline 6 & PVA & 0.00 & 0.0 & - & - & 250 \\
\hline 7 & $\begin{array}{c}\text { Benzene }+ \\
\text { Al-isopropoxide }\end{array}$ & - & - & - & - & - \\
\hline
\end{tabular}

* 1 mole PVA $=1$ mole VA units in $600 \mathrm{ml}$ reaction mixture. + Calculated from the IPA content of the total distillate. $\ddagger$ Calculated according to Eqn (1). $\$$ Not determined. $\|$ Oxalic acid (3g) present as catalyst. 
with PVA, while Al-isopropoxide seems to autocatalyze the secondary and tertiary reactions preferentially, at practically constant Al-content.

Figure 1 shows that in all cases the reaction rates decrease rapidly; after approx $5 \mathrm{hr}$, practically no further reaction occurs. The IPA production (see Fig. 2) suggests first order kinetics in Al-isopropoxide concentration but it should be noted that the reaction system is heterogeneous.

Examination of the TGA results (Table 1) reveals that only the catalyzed modification of PVA, leads to more thermostable products containing 6.8 mole $\mathrm{Al} / 100$ mole VA units. The reproducibility of the rise in decomposition temperature from 250 to $285^{\circ}$ has been confirmed. Assuming only monofunctional reaction according to Eqn (2),

$$
\begin{gathered}
\sim \mathrm{CH}_{2}-\underset{\mathrm{CH}}{\mathrm{CH}}+\mathrm{Al}\left(\mathrm{OC}_{3} \mathrm{H}_{7} \text { iso }\right)_{3} \rightarrow \\
\sim \mathrm{CH}_{2}-\underset{\mathrm{O}}{\mathrm{CH} \sim}+\mathrm{C}_{3} \mathrm{H}_{7} \mathrm{OH} \text { iso } \\
\stackrel{\mathrm{Ol}\left(\mathrm{OC}_{3} \mathrm{H}_{7} \text { iso }\right)_{2}}{\mathrm{O}}
\end{gathered}
$$

it follows that, in the product from experiment 5 , one out of every fifteen OH-groups of PVA has reacted with Al-isopropoxide. It seems possible that only a few OH-groups, viz. those in the "head-to-head" configuration, are responsible for the primary decomposition on heating and that these vicinal OH-groups react with $\mathrm{Al}$-isopropoxide more readily than the others.
This interpretation agrees with the conclusions of Flory and Leutner [7] about anomalous additions in vinyl polymerization. They reported that $2 \%$ anomalous additions, corresponding to $4 \%$ vicinal $\mathrm{OH}-$ groups, are likely in vinyl acetate polymerization. Since we have found a somewhat higher degree of alumoxy substitution $(6.8 \%)$ necessary to give increased thermostability, it is probable that the alumoxy modification also stabilizes other labile $\mathrm{OH}-$ groups, e.g. end-groups and groups adjacent to unhydrolysed acetate groups, amounting to approx $2 \%$.

The physical properties of alumoxy-polyvinyl alcohol will be further investigated. In addition, the reaction of PVA with other aluminium alkoxides will be dealt with.

Acknowledgements - -The authors are indebted to Prof. Dr D. Heikens for his kind interest and one of the authors (R.H.) to the Dutch Ministry of Education and Science for a research fellowship. The authors thank $\mathrm{Mr}$ J. Coumans for technical assistance with analytical measurements.

\section{REFERENCES}

1. Hippe R., Bull. Acad. pol. Sci. Sér. Sci. Chim. 21, 529 (1973).

2. Hippe R., ibid 23, 77 (1975).

3. Hippe R., ibid 21, 533 (1973).

4. Carraher Ch. E. Jr and Thore L., J. Polym. Sci. Part A-1 9, 975 (1971).

5. French Patent 1064073 (1954), C.A. 52, 12895 (1958).

6. D'Alelio G. F., Experimental Plastics and Synthetic Resins Wiley, New York (1955).

7. Flory P. J. and Leutner F. S., J. Polym. Sci. 3, 880 (1948). 